Article

\title{
Negative Consequences of Innovation-Igniting Urban Developments: Empirical Evidence from Three US Cities
}

\author{
Ahoura Zandiatashbar ${ }^{1, *}$ and Carla Maria Kayanan ${ }^{2}$ \\ ${ }^{1}$ Department of Urban and Regional Planning, San José State University, San José, CA 95192, USA; \\ E-Mail: ahoura.zandiatashbar@sjsu.edu \\ 2 School of Geography, University College Dublin, Dublin 4, Ireland; E-Mail: carla.kayanan@ucd.ie \\ * Corresponding author
}

Submitted: 27 March 2020 | Accepted: 18 June 2020 | Published: 29 September 2020

\begin{abstract}
Emergent economic development policies reflect the challenges urban growth coalitions face in attracting the footloose tech-entrepreneurs of the global economy. This convergence between the focus on place and the harnessing of global capital has led to the proliferation of innovation-igniting urban developments (IIUD) - place-based economic development strategies to boost the local knowledge economy. Economic developers are using IIUD strategies to convert areas of the city into entrepreneurial "launch pads" for innovation. However, because these developments remain young, considerations to implement IIUDs lack an evidence-base to show the potential for negative consequences on the communities where they are embedded. This research addresses this gap through: 1) a review of studies of similar developments to identify negative consequences; and 2) using a quasi-experimental method composed of Propensity Score Matching and Average Treatment Effect analyses from IIUDs in three US cities (Boston, MA, St. Louis, MO, and Buffalo, NY). Combined, results demonstrate that the greatest implications of IIUDs are the increased polarized division of labor, housing unaffordability, and income inequality. As IIUDs gain in popularity, it is critical to correlate negative consequences with IIUDs to inform economic developers in assessing trade-offs.
\end{abstract}

\section{Keywords}

innovation-igniting urban development; knowledge economy; local economic development; place-based policies; placemaking

Issue

This article is part of the issue "Planning for Local Economic Development: Research into Policymaking and Practice" edited by Godwin Arku (University of Western Ontario, Canada) and Evan Cleave (Ryerson University, Canada).

(C) 2020 by the authors; licensee Cogitatio (Lisbon, Portugal). This article is licensed under a Creative Commons Attribution 4.0 International License (CC BY).

\section{Introduction}

Policymakers and economic developers continually search for tools to transition post-industrial and lagging economies into knowledge economies (Bell, 1976; Porat \& Rubin, 1977; Yigitcanlar, O'connor, \& Westerman, 2008). This is evident from the influx in place-based polices aimed at concentrating the knowledge economy in the city. Despite the differences in their names and constitution (i.e., the university park captures research spillovers, the innovation district may not include the presence of a university, the creative district may target creative, as well as tech workers), one commonality that binds these developments is the focus on place (Drucker, Kayanan, \& Renski, 2019; Zandiatashbar \& Hamidi, 2018). While there exists a wide-ranging body of scholarship on the role of place in increasing the attractiveness and value of the city, much of which draws connections between the City Beautiful Movement (Hall, 2004), urban renewal (Page \& Ross, 2017), tactical urbanism (Lydon \& Garcia, 2015), and placemaking practices (Fincher, Pardy, \& Shaw, 2016), the contribution of this article is in draw- 
ing the connection between the role of place in local economic development practices focused on siting innovative activity in the city.

In an effort to attract the firms, talent, and supports considered necessary for innovation, innovationigniting urban developments (IIUD), as we label them in this article, are rapidly budding up in cities across the globe (Hamidi \& Zandiatashbar, 2019a; Shearmur, 2012). IIUDs, which are often developed over post-industrial sites-such as Boston's Seaport Innovation District in the South Boston Waterfront (Drucker et al., 2019) or 22@BCN built over Barcelona's Poblenou neighborhood (Charnock \& Ribera-Fumaz, 2011)-rely on a master plan for the designated area of development. These sites depend heavily on design and placemaking to create an entrepreneurial ecosystem attractive to the firms and individuals closely associated with startup activities and the technology sector (Acs, Stam, Audretsch, \& O'Connor, 2017; Rossi \& Di Bella, 2017). IIUD best practices and accompanying rhetoric suggest that design and placemaking are necessary factors to foster a vibrant and engaging environment conducive to the constant and spontaneous interaction integral to innovation (Chesbrough, Vanhaverbeke, \& West, 2006). Innovation districts are a good example of IIUDs, as are extensions of college campuses, such as Cortex Innovation Community in Saint Louis, MO, and Buffalo's Niagara Medical Campus in Buffalo, NY (Drucker et al., 2019).

As the building of IIUDs trends, it becomes necessary to consider potential negative consequences and associated policy solutions (Peck, 2005; Scott, 2006). However, IIUDs are young developments and this challenges the ability to derive a concrete evidence-base of negative consequences. We address this through a mixed-method approach that incorporates: 1) a synthesis review of theoretical and empirical works explaining potential negative consequences and counter-empirical studies testing such consequences; and 2) a quasi-experimental analysis of empirical cases composed of Propensity Score Matching (PSM) and Average Treatment Effect (ATE) analyses from three prominent cases in the United States (Boston's Seaport Innovation District, MA, Cortex Innovation Community in Saint Louis, $\mathrm{MO}$, and Buffalo Niagara Medical Campus [BNMC] in Buffalo, NY). Results show that IIUDs correlate strongly with a polarized labor division and issues of housing unaffordability.

This article is structured in four parts. The first part details the structural factors contributing to IIUDs. The second part uses examples of existing IIUDs to discuss four prominent negative consequences of these emergent spatial forms. The third section includes empirical findings from IIUDs in Boston, St. Louis, and Buffalo. The final section points to policy suggestions that can be used by urban development actors to mitigate the negative consequences of a continuing (and growing) trend in IIUDs that our empirical analyses confirmed.

\section{Urban Development and the Siting of Innovation-Related Activity in the City}

Over the last thirty years cities have undergone the resurgence of property-led regeneration programs (Turok, 1992). These developments have taken various forms and have targeted different sectors, for example, tourism (Smyth, 2005), waterfront development (Fainstein, 2008), arts (García, 2004), sports (Hall 2004), and of interest to this article, knowledge-based urban developments (Carrillo, Yigitcanlar, García, \& Lönnqvist, 2014). The process of regenerating cities and making them more knowledge-intensive has contributed to policy prescriptions aimed at attracting young talented workers (Florida, 2002). The 2008 Global Financial Crisis and ensuing recession intensified the financialization of the urban property market (Aalbers, 2020) and placed increased emphasis on IIUDs to restart the economy, which has contributed to economic developers more directly engaging with placemaking principles (Kayanan, Eichenmüller, \& Chambers, 2018). From the perspective of an evolving economic development practice, we identify three structural changes that contribute to the contemporary focus on place.

\subsection{State Descaling}

The first factor contributing to economic developers' contemporary focus on place is the descaling of the state (Harvey, 1989). Though not directly tied to theories on the practice of economic development, a wide scholarship exists on how descaling impacts the (re)development of the city and its governance. As a political objective, descaling has created pathways for private capital to interject in urban development (Harvey, 1989). Descaling imperatives do not necessarily come with financial supports, meaning that local governments are often left to scramble for financial resources, such as public private partnerships (Fainstein, 2001) or tax increment finance schemes (Weber, 2014). This form of collaboration is evident in innovation district strategies, which brings together a wide range of actors - to include representatives from the private, public, education, and civic spheres-working together to bring the innovation district to fruition (B. Katz \& Bradley, 2013).

\subsection{Economic Developers' Engagement with Science and Technology Policies}

The second factor in a changing economic development practice more closely tied to place is economic developers engaging with science and technology policies. Prior to the 1980s, rarely did state economic development agencies focus on science and technology policies (Plosila, 2004). Within the urban realm in the western world, economic developers' engagement with industrial districts through to the 1980 s existed at the state level and primarily consisted in the form of building 
factories (Plosila, 2004). Increasing linkages with higher education and research institutions and discussing the role of talent and venture capital as economic development packages, activities related to supporting science and technology, came only in the 1980s after the success of planned science and research parks in Boston (Route 128), Silicon Valley (Stanford Research Park), and North Carolina (Research Triangle Park) were taking effect (Markusen, 1999; Saxenian, 1996). With the descaling of the state, economic developers, now working at the regional level, built upon the agglomeration benefits of the industrial districts (Marshall, 1890) to focus on clustering research and development activity (Fallah, Partridge, \& Rickman, 2013). The onset of neoliberalism and entrepreneurial urban development (Harvey, 1989), opened up the need for city-regions to play a heavier hand in driving tech-based visions (Clark, 2014).

\subsection{Urbanizing the Economy}

The third factor contributing to local economic developers' engagement with place is the focus on the city-in both theory and in practice-as a generator of regional wealth and competitiveness (Glaeser, 2011). Evidence of this are calls by think tanks for the development of metropolitan-scale governance through the implementation of metropolitan mayors (B. Katz \& Bradley, 2013), as well as the (OECD, 2015) encouraging policy prescriptions and spatial configurations that center economic activity within the metropolitan sphere (D'Albergo \& Lefèvre, 2018; Kayanan, Moore-Cherry, \& Tomaney, 2020). As discussed above, the shift from building IIUDs on suburban greenfield sites and pastoral environments to siting them in the city (Mozingo, 2016) add further supports to urbanizing the economy. For clarity on the connection between the urbanization of the economy and IIUDs, below we isolate two reasons that directly correlate with policies targeting innovative activity in the city: agglomeration logics and demographic preferences.

\subsubsection{Agglomeration}

The siting of innovation-related activity in the city is undergirded by agglomeration logics. Scholarship on agglomeration supports the idea that spatial clustering leads to specialization externalities of agglomeration by catalyzing spillover effects such as frequent knowledge exchange between similar industries, lower access cost to the larger labor pool and suppliers, and ultimately the product's value chain (Shearmur, 2012). Several empirical studies also confirm that such externalities of the agglomeration economy determine location patterns and innovation productivities of knowledgebased businesses. Building on this hypothesis, Boschma (2005) stated that the spatial proximity leading to knowledge spillover could be more effective when coupled with cognitive proximity. Cognitive proximity refers to the required knowledge similarity for intra- and inter- firm knowledge transfers and highly depends on an individual's level of knowledge, or in the aggregate, a knowledgeable workforce. A recent study of Canadian knowledge-based firms also shows that proximity to a larger pool of talented workers and university graduates play a critical role in their location pattern (Shearmur, 2012).

\subsubsection{Demographic Preferences}

The principle pillar of the placemaking strategies in IIUD policies is the local place-based characteristics that satisfy the life quality of skillful millennials, such as their carfree lifestyle and strong desire for urban social life, mixeduse and compact neighborhoods, transit quality, and walkable proximity to restaurants, retail, cultural, and educational institutions (Florida, 2002; Shearmur, 2012; Zandiatashbar, Hamidi, Foster, \& Park, 2019). For instance, transportation infrastructure is often integrated in these policies as walkability and access to public transit are key characteristics of IIUDs (B. Katz \& Bradley, 2013). Several European, American and Asian empirical studies show that college-educated millennials and members of the creative class have become more carfree and are more drawn to neighborhoods with walking and transit access to job and place-quality amenities (Credit, 2017; Weissmann, 2012; Zandiatashbar \& Hamidi, 2018). On the other hand, public transit infrastructure reduces travel time and enhances the urbanization externalities of agglomeration by expanding the coverage area of a business. Furthermore, transit riders have more opportunities for face-to-face encounters leading to knowledge exchange (Chatman \& Noland, 2011).

\section{Method}

Our discussion on the negative consequences of the IIUDs is built upon a mixed method of synthesis review and empirical analysis. First, we provide a summary of a pair-wise synthesis review of the theoretical and empirical works on each of the negative consequences. Second, as IIUDs are still young, resulting in a lack of empirical studies, we also include a series of analysis of three cases in the US: the Seaport Innovation District, in Boston, MA; Cortex Innovation Community (Cortex), in St. Louis, MO; and BNMC in Buffalo, NY. Figures 1-3 briefly summarize the location and history of each city's respective IIUD.

\section{IIUDs and Their Negative Consequences-Synthesis Review}

Having arrived at a theoretical understanding of why local economic developers engage with place and a contextual understanding behind IIUDs, we now shift our attention to the negative consequences that emerge from such place-based strategies. It is important to note that these negative consequences are not listed in chronological order. In addition, there is no guarantee that 


\section{COGITATIO}

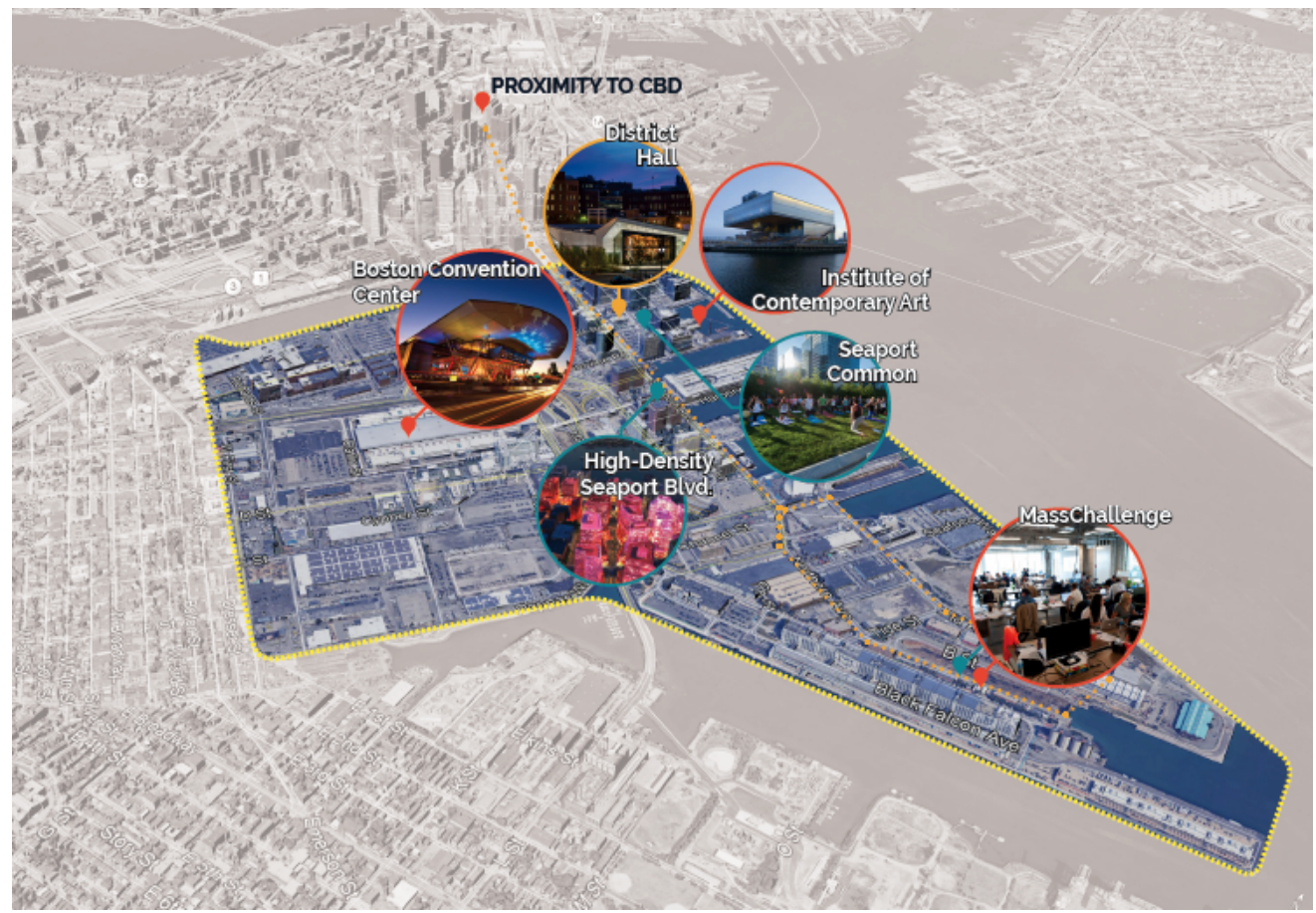

Figure 1. Boston Seaport Innovation Districts (BSID; Boston, MA). In 2010 Mayor Menino declared intentions to build the Boston's Seaport Innovation District. A master plan for the northernmost part of the peninsula was developed to tighten the connection between igniting innovation and placemaking. Only a few developments existed in the area prior. Incubators, free wi-fi connected spaces, and dorm-like housing for entrepreneurs formed the strategy. Boston's IIUD strategy focused on startup and tech-entrepreneurship but remained sector agnostic (Drucker et al., 2019). Image source: Hamidi and Zandiatashbar (2019b).

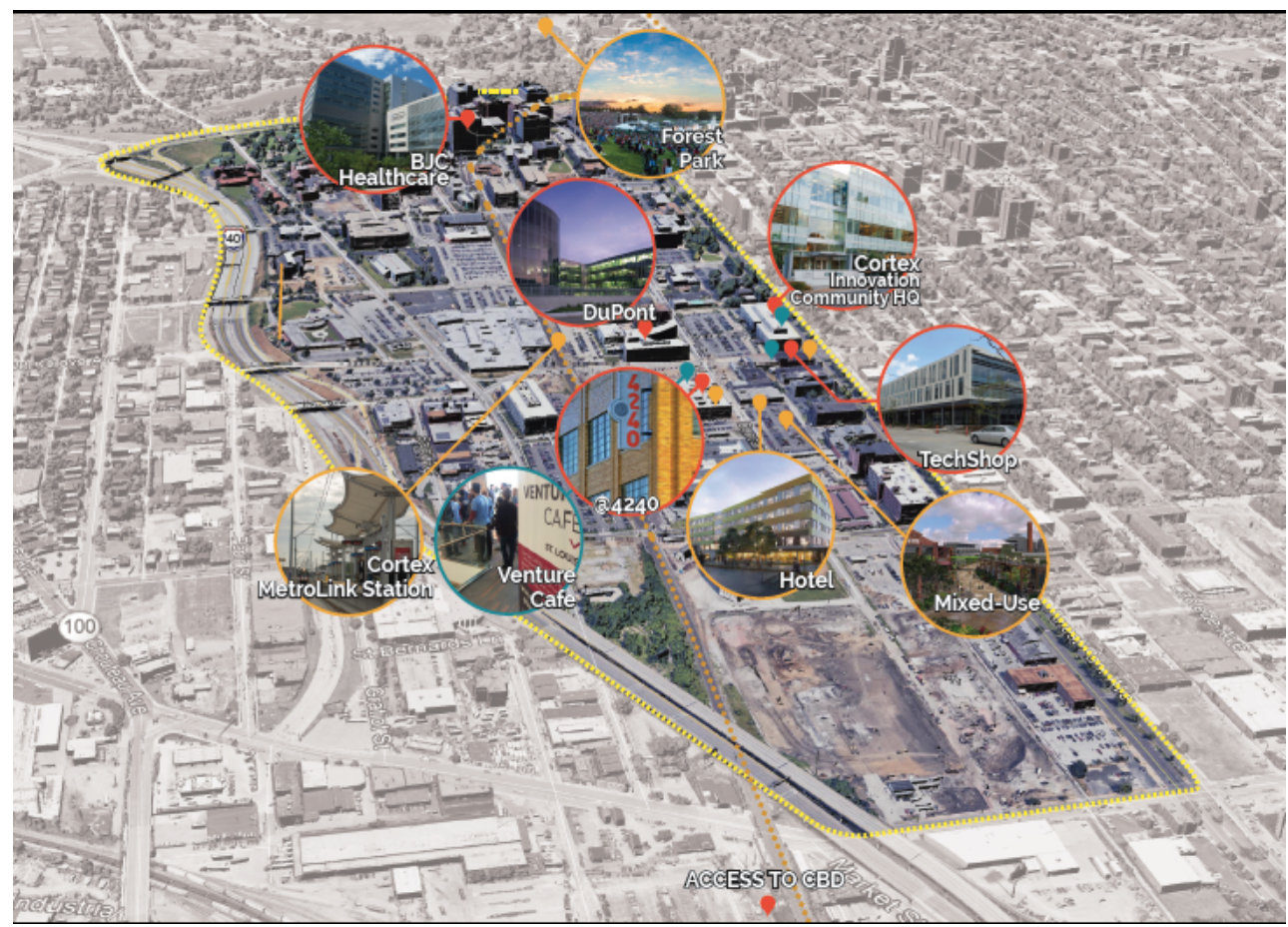

Figure 2. Cortex Innovation Community (Cortex; Saint Louis, MO). As a legal entity, Cortex was established in 2002 following a series of attempts to create a research corridor between St. Louis University, Washington University, and BJC Healthcare research medical center. In 2010, Cortex was reimagined as an innovation district and renamed the Cortex Innovation Community. Incubators, hospital and university anchors, boutique hotels, and open spaces for quick wi-fi connectivity are all located within the designated space (Drucker et al., 2019). Image source: Hamidi and Zandiatashbar (2019b). 


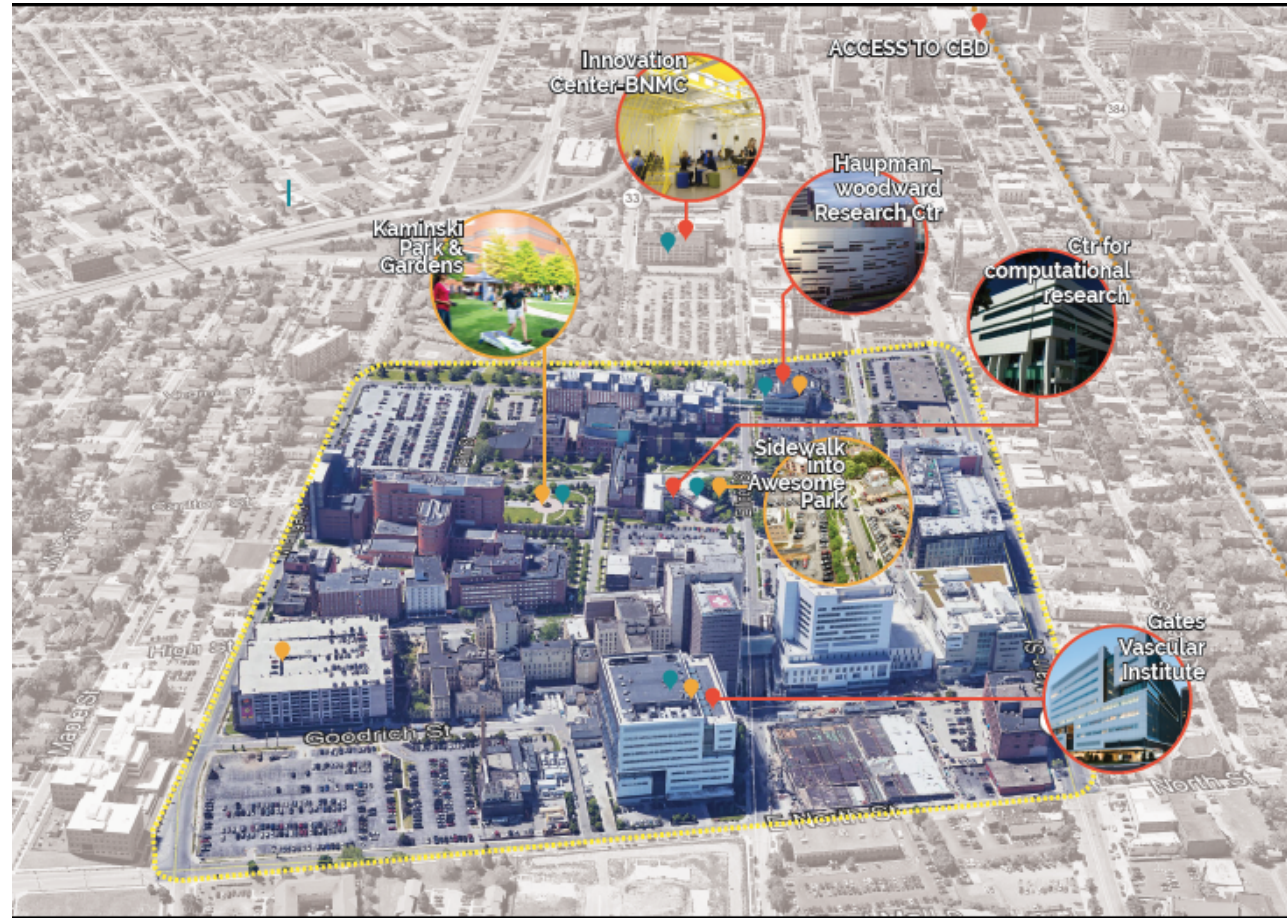

Figure 3. Buffalo Niagara Medical Campus (BNMC; Buffalo, NY). The BNMC is a medical innovation district established in 2002 in Buffalo, NY. It includes a medical campus, new hospitals, private-sector companies, and social innovators. Placemaking efforts in the form of street renovations and expansion of clinical, research, office, medical, and coworking spaces formed the strategy (Hamidi \& Zandiatashbar, 2019b). Image source: Hamidi and Zandiatashbar (2019b).

one IIUD will exhibit all four negative consequences. However, based on an analysis of the existing literature of knowledge-intensive developments across the globe, below we list the most common negative consequences. Although the empirical studies did not focus on urban developments, we strengthened our argument by including empirical analyses of three cases of IIUDs in the US. Table 1 provides a matrix of the negative consequences reported from our literature synthesis. The matrix separates theoretical works from empirical studies for each negative consequence.

\subsection{Negative Consequence 1: Polarized Labor Division}

IIUDs promote high-tech clusters and are primarily dependent on two classes of the labor force: low-wage, unskilled workers (Rifkin, 1995) and high-skilled professionals (Florida, 2002). Policies that support the development of IIUD devote more focus on high-skilled professionals. Because these individuals are critical to hightech growth, ample literature has addressed their lifequality amenities (Florida, 2014). This prioritizing of the high-skilled professional class in both the literature, in policy, and in practice often means that low-wage, unskilled workers are disregarded. When IIUDs do address job opportunities for these individuals it is done by rationalizing development in or near low-income neighborhoods as creating employment opportunities close to work. The lack of attention to low- or mid-wage jobs in these types of developments results in tangible gaps in terms of wage, job security, social position, wealth, education, and quality of life (Scott, 2006). High-skilled workers migrate to areas when the local workforce is unable to fill the demand for high-skilled jobs. This inflow migration of high-skilled professionals helps the high-tech economy grow and allows high-tech job opportunities to continuously emerge, while a higher portion of the original low-wage, unskilled residents might not have the opportunity to move into the high-skilled professional category. A shrinking middle class increases the gap between these two classes and deepens the social division of labor caused by the lack of equity in distribution of opportunities (McCann, 2007). Equity warnings related to progrowth local development policies is not a new concern. Back in the early 1990s, Bartik (1991) discussed the distributional issues of economic development policies and pointed to their disregard in practice.

Economic segregation in US regions is positively associated with a stronger high-tech industry, higher percentage of a creative class workforce and college grads, and innovation intensity led by knowledge clusters (Berkes \& Gaetani, 2019; Florida \& Mellander, 2016). For instance, in Austin's creative city-region, the high-technology sector grew in the late 1990 s and, over time, contributed to an income gap between the creative professionals and the city's poor, many of whom are African American and Latinx (McCann, 2007). During the 1990s, $13.1 \%$ of the city's population was living in poverty compared with the US average of $12.7 \%$. Furthermore, in this period, the average wage in the high-tech sector increased by $\$ 26,500$. 
Table 1. Summary of literature synthesis.

\begin{tabular}{|c|c|c|c|}
\hline \multirow[b]{2}{*}{$\begin{array}{l}\text { Negative } \\
\text { Consequence }\end{array}$} & \multirow[b]{2}{*}{$\begin{array}{l}\text { Theoretical } \\
\text { Study Author(s) }\end{array}$} & \multicolumn{2}{|r|}{ Empirical Study } \\
\hline & & Author(s) & $\begin{array}{l}\text { (Supportive of/Contradicting the Negative } \\
\text { Consequence) Finding Summary }\end{array}$ \\
\hline \multirow[t]{3}{*}{$\begin{array}{l}\text { Polarized Labor } \\
\text { Division }\end{array}$} & \multirow{3}{*}{$\begin{array}{l}\text { Scott }(2006) ; \\
\text { Peck (2005); } \\
\text { Donegan \& } \\
\text { Lowe (2008) }\end{array}$} & $\begin{array}{l}\text { Berkes \& } \\
\text { Gaetani (2019) }\end{array}$ & $\begin{array}{l}\text { (Supportive) Innovation intensity led by knowledge } \\
\text { clusters is responsible for } 20 \% \text { increase in the city's } \\
\text { segregation between } 1990 \text { and } 2010 \text {. }\end{array}$ \\
\hline & & $\begin{array}{l}\text { Florida \& } \\
\text { Mellander (2016) }\end{array}$ & $\begin{array}{l}\text { (Supportive) Economic segregation in US regions is } \\
\text { positively associated with stronger high-tech industry } \\
\text { and creative class workforce. }\end{array}$ \\
\hline & & McCann, (2007) & $\begin{array}{l}\text { Supportive: In Austin the gap between high-tech } \\
\text { workers and other industries has increasing led to a } \\
\text { wider gap. }\end{array}$ \\
\hline \multirow[t]{2}{*}{$\begin{array}{l}\text { Housing } \\
\text { Unaffordability }\end{array}$} & \multirow{2}{*}{$\begin{array}{l}\text { Donegan \& } \\
\text { Lowe (2008); } \\
\text { Bevilacqua, } \\
\text { Pizzimenti, and } \\
\text { Maione (2020); } \\
\text { Voith \& } \\
\text { Wachter (2009); } \\
\text { Catungal \& } \\
\text { Leslie (2009) }\end{array}$} & Florida (2017); & $\begin{array}{l}\text { (Supportive) Gentrification between } 2000 \text { and } 2007 \\
\text { positively correlates with the concentration of } \\
\text { high-tech industries, share of science and technology } \\
\text { workers, and artistic and cultural activities across } \\
\text { US metros. }\end{array}$ \\
\hline & & $\begin{array}{l}\text { Grodach, Foster, } \\
\text { and Murdoch (2018) }\end{array}$ & $\begin{array}{l}\text { (Contradicting) Not all creative industries play a } \\
\text { significant role in gentrification and displacement in } \\
\text { the US. Growth of fine and commercial arts } \\
\text { establishments are weakest in gentrifying } \\
\text { US neighborhoods. }\end{array}$ \\
\hline $\begin{array}{l}\text { Unequal Access } \\
\text { to Opportunities }\end{array}$ & $\begin{array}{l}\text { Scott (2006); } \\
\text { Gouldner (1979) }\end{array}$ & $\begin{array}{l}\text { Weinreich, Hamidi, } \\
\text { Bonakdar, Sardari, } \\
\text { and Moazzeni (2019) }\end{array}$ & $\begin{array}{l}\text { (Supportive) Dallas, TX experienced a strong job } \\
\text { growth as the result of attracting high-tech } \\
\text { industries; however, only } 4 \% \text { of Dallas' residents } \\
\text { who live in the transit dependent core have access to } \\
\text { regional jobs via transit. }\end{array}$ \\
\hline \multirow[t]{3}{*}{$\begin{array}{l}\text { Socio-Spatial } \\
\text { Polarization }\end{array}$} & \multirow[t]{3}{*}{ Scott $(2001,2006)$} & McCann (2007) & $\begin{array}{l}\text { (Supportive) The victims of housing unaffordability } \\
\text { and the wage gap in Austin are members of mostly } \\
\text { African American and Latinx communities who } \\
\text { moved out of the high-tech clusters. }\end{array}$ \\
\hline & & Zlolniski, (2006) & $\begin{array}{l}\text { Supportive: Spatial colonies of low-wage Mexican } \\
\text { workers in Silicon Valley, a major global tech hub, } \\
\text { where there exists an increasing number of workers } \\
\text { in unstable and low-paid status. }\end{array}$ \\
\hline & & $\begin{array}{l}\text { Modai-Snir \& } \\
\text { van Ham (2018) }\end{array}$ & $\begin{array}{l}\text { (Supportive) Integration in global economy and use } \\
\text { of IIUD for urban developments to attract high-tech } \\
\text { jobs and talented workers played a major role in } \\
\text { intensifying the socio-spatial divide in Tel Aviv } \\
\text { metropolitan area. }\end{array}$ \\
\hline
\end{tabular}

The average rise in wages for all industries, including high-tech, was only $\$ 18,000-$ a growth in line with the US average (McCann, 2007).

\subsection{Negative Consequence 2: Housing Unaffordability}

Housing unaffordability, gentrification, and displacement are points of tension related to urban development for their tangible impact on local residents (Voith \&
Wachter, 2009). The siting of innovation-related activity in the city contributes to the problem by creating opportunities only for high-skilled workers who can afford to live in close proximity to these jobs.

The place-based strategies that aim to attract hightech firms have led to the significant role of real estate development companies in satisfying the strong demand for urban transformations (Bevilacqua et al., 2020). This urban transformation is tied strongly to 
place-based amenity richness (McCann, 2007). Such amenity richness fosters an elevated quality of life that attracts the creative class, while also increasing housing prices. Disadvantaged populations are removed in order to make place attractive for capital (Catungal \& Leslie, 2009; McCann, 2007) and the extensive introduction of place-quality amenities into these neighborhoods have become the standard descriptors to be appreciated by the high-skilled professionals who can afford it. Since the demand side is fulfilled, the increase in housing price continues (Fingleton, 2008). Urban real estate frameworks, such as the ones by Alonso (1964), Roback (1982), and Rosen (1974), explain the spatial equilibrium dynamic causing this negative consequence as such: Improvements to an urban area in the form of a rise of high-wage jobs and the extensive injection of place-quality amenities, all else equal, causes a demand increase. If the supply function does not change, then the equilibrium price will increase as a function of market clearing. As the result of this dynamic, local residents and renters will be priced out of the market. Without an adequate pre-growth management agenda in place, price increase will not stop due to this supply-demand dynamic.

Empirical evidence in the US also supports the fact that gentrification (defined as the share of neighborhoods in a region that escalated from the bottom half to the top half in distribution of home prices between 2000 and 2007) positively correlates with the concentration of high-tech industries, share of science and technology workers, and artistic and cultural activities across US metros (Florida, 2017). The initial plans for the Boston Seaport Innovation District (BSID), which was launched in 2010 following the 2008/9 recession as Mayor Menino's initiative for the South Boston Waterfront, included the provision of affordable housing units. However, with the uptick of the rental market in the South Boston Waterfront, these aims were discarded (Drucker et al., 2019). Rather than build the $20 \%$ required affordable housing into new developments, contracted developers were given permission to contribute money into a fund for development of affordable housing units elsewhere. Even the lack of affordable housing for high-skilled professionals is problematic and can lead to what Florida (2017) has called the 'flight of the creative class.' Dublin, which has witnessed a post-crash revival due in part to the expansion of the tech sector with large companies such as Google, Facebook, Airbnb, and many others located in the city center, is facing a housing affordability crisis across all income classes (Kayanan \& Pajević, 2020).

\subsection{Negative Consequence 3: Unequal Access to Opportunities}

Without pre-growth management strategies in place, the growth of the high-tech economy in the city can result in negative impacts for communities at a regional scale. Local decision makers working to foster a local knowledge economy by attracting high-tech firms through tax abatements often negate to consider-or outwardly disregard-potential future negative consequences of their decisions at larger scales (Stiglitz, 2016). The concentration of urban amenities and economic growth in a designated urban area that is exclusive to the highly educated members of society could result in what Gouldner (1979) first called 'the dark side of the dialectic' and later Scott (2006) explained as the 'source of localized competitive advantage.'

Several high-tech clusters suffer from the lack of regional planning to provide a pre-growth agenda matched with accurate infrastructural capacities (Downs, 2005). In the case of Austin, the high-tech boom led to inequality, traffic congestion, urban sprawl, and environmental issues. The same issues are now raised in DallasFort Worth Motorplex in North Texas, where cities offered ample tax incentives and are heavily focused on local place-based strategies to attract high-tech firms (Zandiatashbar, Hamidi, \& Foster, 2019). Despite increases in job opportunities, a recent study shows how transit-dependent populations in Dallas do not benefit from this growth due to congestion increase and lack of supportive transit access (Weinreich, Hamidi, Bonakdar, Sardari, \& Moazzeni, 2019). Silicon Valley, which is the prime model for innovation-based economic prosperity, has the fifth worst congestion in the world (Pishue, 2017). Housing shortage and ongoing transportation challenges constrain the growth of the Bay Area. While average monthly housing costs and apartment rental rates in the Bay Area are the highest in the nation, proximity to high-tech clusters exacerbate challenges to housing affordability. Workers locate further from employment centers and, due to the lack of enhanced regional multimodal mobility amenities, congestion grows. The increased commute times of Silicon Valley workers has resulted in an estimated $\$ 2.7$ billion yearly loss in productivity (Joint Venture Silicon Valley, 2019).

\subsection{Negative Consequence 4: Socio-Spatial Polarization}

The polarized division of labor caused by the concentration of high wage jobs in IIUDs where housing unaffordability deters middle- and low-income households will result in uneven urban and regional economic development. One outcome of this uneven regional growth is the spatial concentration of low-wage workers in more affordable, mostly suburban areas (Scott, 2006). In several cases, local residents who face the negative consequences of the creative economy are also members of racially disadvantaged communities. Ample evidence shows that the members of racially marginalized communities tend to collocate with members of similar racial and socio-economic status (White, 1983). For instance, the victims of housing unaffordability and the wage gap in Austin are members of mostly African American and Latinx communities who moved out of the high-tech clusters (McCann, 2007). This is also evident in the spatial colonies of low-wage Mexican workers in Silicon Valley, 
where there exists an increasing number of workers in unstable and low-paid status (Zlolniski, 2006). Several subcontracting agencies hire low-wage workers for entrylevel custodial jobs comprised mostly of low-wage and undocumented Mexican immigrant workers (Zlolniski, 2006). In both the Austin and Silicon Valley cases, lowwaged unskilled workers tend to cluster on affordable peripheries, which ultimately form the poor spatial patches in these high-tech regions.

\section{Empirical Analysis of the Four Negative Consequences in Three US Cases}

We adopted a quasi-experimental research design to assess the four negative consequences discussed above. Our focus was on whether implementation of IIUDs could result in an increased share of high-wage jobs, thus resulting in housing unaffordability, unequal access to opportunities, and income inequality (Osei \& Winters, 2018). Our assessment needed to pair two neighborhoods: one within the territory of the IIUD with one outside of it. These neighborhoods needed to share similarities prior to the implementation of the IIUD and have significantly different outcomes after implementation of the IIUD in terms of the shares of high-wage jobs, housing and rent values, and income diversity. This was done through utilizing the PSM technique. PSM pairs any location (census block group) in the affected area by the IIUD (within a 1-mile buffer of IIUD boundary) with the most similar location outside of the affected area using the characteristics explained in Table 2. We conducted three PSMs, one for each case, including a series of variables to control for location and socioeconomic at- tributes of census block groups prior to the implementation of each respective IIUD. The PSM was implemented in Stata 16 using the PSmatch2 package and a caliber (maximum permitted difference between matched subjects) of 0.25 based on ample recommendation in the literature (Cochran \& Rubin, 1973). Once pairing through PSM was completed, we calculated the ATE of IIUD on share of high-wage jobs, housing and rent value, and income diversity in 2018 to assess whether the share of high-wage jobs increases as the result of the IIUD, thus triggering housing unaffordability and income inequality.

Our study area for each IIUD is their hosting counties (BSID is in Suffolk county, Cortex is in St. Louis county, and BNMC is in Erie county). Our PSM analyses matched treated neighborhoods by IIUD with exactly similar control neighborhoods. First, we used Principal Component Analysis (PCA) to develop a measure of socio-economic status attributes of neighborhoods in 2000 composed of $\%$ of residents with college or higher degree, \% of employed working age residents, and income per capita. The results of these PCAs are reported in Table 3 and we used comp. 1 for our PSM analysis.

Second, we matched the treated neighborhoods by the IIUD (within a 1-mile distance from the designated area) based on the socio-economic status measures and distance to the Central Business District. We selected the Central Business District for two reasons: 1) to ensure both treated and control neighborhoods are similar in terms of access to the market core, and 2) in all three cases, IIUD areas are adjacent to the Central Business District which could make our comparisons biased. Then ATE analysis between the treated and control neighborhoods shows the impact of the IIUD on housing unaf-

Table 2. Descriptions and sources of model variables.

\begin{tabular}{llll}
\hline & Variable & Definition & Source \\
\hline $\begin{array}{l}\text { Outcome variables: } \\
\text { assessed in 2018 after }\end{array}$ & High Wage \% & $\begin{array}{l}\text { Percentage of high wage jobs (with earnings } \\
\text { greater than } \$ 3333 / \text { month) in 2017 }\end{array}$ & US Census Bureau (2017)
\end{tabular}

the implementation of the IIUD

Housing_Value Median housing value

Rent

Inc_Div ${ }^{1}$

\section{Median rent value}

Income diversity was measured using Simpson's Index of Diversity of four consolidated census income categories: low income (US\$0 to 24.9k), low middle income (US\$25k to 59.9k), high middle income (US\$60k to $99.9 \mathrm{k}$ ) and high income (above US\$100k) households

\begin{tabular}{llll}
$\begin{array}{l}\text { Matching variables: } \\
\text { pre-IIUD; matching }\end{array}$ & Clg \% & \% of residents with college degree and higher & Census (2000) \\
$\begin{array}{l}\text { IIUD neighborhoods } \\
\text { with non-IIUD }\end{array}$ & Income & Income per capita in 2000 & Census (2000) \\
neighborhoods in 2000 & CBD \% & \% of employed residents & Census (2000) \\
\hline
\end{tabular}

US Census Bureau (2018)

US Census Bureau (2018)

US Census Bureau (2018) 
Table 3. PCA results for socio-economic status single combined measure.

\begin{tabular}{|c|c|c|c|c|c|c|}
\hline & Components & Eigenvalue & Emp \% & Clg \% & Income & \# of Observations \\
\hline \multirow[t]{3}{*}{ BSID } & Comp. 1 & 1.87 & 0.42 & 0.64 & 0.65 & 603 \\
\hline & Comp. 2 & 0.81 & 0.90 & -0.33 & -0.27 & \\
\hline & Comp. 3 & 0.32 & 0.05 & 0.70 & -0.72 & \\
\hline \multirow[t]{3}{*}{ Cortex } & Comp. 1 & 2.16 & 0.51 & 0.56 & 0.62 & 353 \\
\hline & Comp. 2 & 0.60 & 0.85 & -0.47 & -0.25 & \\
\hline & Comp. 3 & 0.24 & 0.14 & 0.65 & -0.74 & \\
\hline \multirow[t]{3}{*}{ BNMC } & Comp. 1 & 2.12 & 0.49 & 0.60 & 0.63 & 726 \\
\hline & Comp. 2 & 0.67 & 0.86 & -0.45 & -0.23 & \\
\hline & Comp. 3 & 0.21 & 0.14 & 0.66 & -0.74 & \\
\hline
\end{tabular}

fordability and income inequality. Table 4 provides the results of ATE, analyzing the impacts of the IIUD in our three cases. BSID and Cortex demonstrate a higher in- crease in housing unaffordability and income inequality. This could be associated with the growth of high-wage jobs and high-income households. For instance, on aver-

Table 4. Results of post PSM ATE analysis, IIUD Impact on housing unaffordability and income inequality in 2018.

\begin{tabular}{|c|c|c|c|c|c|c|c|c|}
\hline & Pair Type & $\begin{array}{l}\text { Avg. } \\
\text { Value }\end{array}$ & Difference & $\begin{array}{l}\text { Standard } \\
\text { Error }\end{array}$ & T-Statistics & P-Value & $\begin{array}{c}\text { \# of Paired } \\
\text { Observations }\end{array}$ & $\begin{array}{l}\text { Outcome } \\
\text { Variable Name }\end{array}$ \\
\hline \multirow[t]{5}{*}{ BSID } & $\begin{array}{l}\text { Treated } \\
\text { Control }\end{array}$ & $\begin{array}{l}\% 48.78 \\
\% 43.75\end{array}$ & $\% 5.02$ & 4.75 & 1.16 & 0.140 & 72 & $\%$ of High-Wage Jobs \\
\hline & $\begin{array}{l}\text { Treated } \\
\text { Control }\end{array}$ & $\begin{array}{l}\% 47.37 \\
\% 35.80\end{array}$ & $\% 11.57$ & 4.98 & 2.32 & $0.002 * *$ & 72 & $\begin{array}{l}\% \text { of High Income } \\
\text { Households (HHs) }\end{array}$ \\
\hline & $\begin{array}{l}\text { Treated } \\
\text { Control }\end{array}$ & $\begin{array}{l}0.58 \\
0.6\end{array}$ & -0.02 & 0.02 & -0.72 & 0.312 & 72 & Income Diversity \\
\hline & $\begin{array}{l}\text { Treated } \\
\text { Control }\end{array}$ & $\begin{array}{l}646.11 \\
464.03\end{array}$ & 182.08 & 90.82 & 2.00 & $0.005 * *$ & 72 & $\begin{array}{l}\text { Median Housing } \\
\text { Value (in 000) }\end{array}$ \\
\hline & $\begin{array}{l}\text { Treated } \\
\text { Control }\end{array}$ & $\begin{array}{l}1680.44 \\
1534.15\end{array}$ & 146.28 & 158.12 & 0.93 & 0.255 & 72 & Median Rent \\
\hline \multirow[t]{5}{*}{ Cortex } & $\begin{array}{l}\text { Treated } \\
\text { Control }\end{array}$ & $\begin{array}{l}\% 34.63 \\
\% 29.92\end{array}$ & $\% 4.72$ & 4.28 & 1.20 & 0.236 & 30 & $\%$ of High-Wage Jobs \\
\hline & $\begin{array}{l}\text { Treated } \\
\text { Control }\end{array}$ & $\begin{array}{l}\% 39.2 \\
\% 33.66\end{array}$ & $\% 5.54$ & 7.75 & 0.72 & 0.435 & 30 & $\%$ of High Income HHs \\
\hline & $\begin{array}{l}\text { Treated } \\
\text { Control }\end{array}$ & $\begin{array}{l}0.57 \\
0.59\end{array}$ & -0.02 & 0.04 & -0.47 & 0.617 & 30 & Income Diversity \\
\hline & $\begin{array}{l}\text { Treated } \\
\text { Control }\end{array}$ & $\begin{array}{l}208.05 \\
147.87\end{array}$ & 60.18 & 36.53 & 1.65 & $0.089 *$ & 30 & $\begin{array}{l}\text { Median Housing } \\
\text { Value (in 000) }\end{array}$ \\
\hline & $\begin{array}{l}\text { Treated } \\
\text { Control }\end{array}$ & $\begin{array}{l}875.27 \\
865.13\end{array}$ & 10.13 & 65.33 & 0.16 & 0.865 & 30 & Median Rent \\
\hline \multirow[t]{5}{*}{ BNMC } & $\begin{array}{l}\text { Treated } \\
\text { Control }\end{array}$ & $\begin{array}{l}\% 30.92 \\
\% 32.34\end{array}$ & $-\% 1.42$ & 9.48 & -0.15 & 0.798 & 25 & $\%$ of High-Wage Jobs \\
\hline & $\begin{array}{l}\text { Treated } \\
\text { Control }\end{array}$ & $\begin{array}{l}\% 8.16 \\
\% 6.67\end{array}$ & $\% 1.49$ & 3.26 & 0.46 & 0.544 & 25 & $\%$ of High Income HHs \\
\hline & $\begin{array}{l}\text { Treated } \\
\text { Control }\end{array}$ & $\begin{array}{l}0.65 \\
0.61\end{array}$ & 0.04 & 0.06 & 0.67 & 0.183 & 25 & Income Diversity \\
\hline & $\begin{array}{l}\text { Treated } \\
\text { Control }\end{array}$ & $\begin{array}{r}108.3 \\
72.6\end{array}$ & 35.70 & 39.96 & 0.89 & 0.138 & 25 & $\begin{array}{l}\text { Median Housing } \\
\text { Value (in 000) }\end{array}$ \\
\hline & $\begin{array}{l}\text { Treated } \\
\text { Control }\end{array}$ & $\begin{array}{l}760.32 \\
702.80\end{array}$ & 58.24 & 72.98 & 0.80 & 0.205 & 25 & Median Rent \\
\hline
\end{tabular}

Note: ${ }^{*}$ P-Value $<0.1 ;{ }^{* *}$ P-Value $<0.01$. 
age, nearly half of the households in the selected neighborhood geographically affected by the IIUD designation command a high-income and half of the total jobs are high-wage. On the contrary, on average, almost only a third of the households in the control neighborhood outside of the IIUD have such high annual income.

Once the IIUD neighborhoods attract more affluent households, income inequality increases. This could explain the nearly $14 \%$ increase in housing value (on average). This trend also had an impact on rent growth, while it appeared to be insignificant according to the observed P-value. We observed almost a similar pattern in Cortex, however not as significant as in Boston and quite different than in Buffalo. Boston is an example of a region needing active controlling policies for smart growth management. What is striking is that in Boston the gap is not between the IIUD (Boston's Seaport Innovation District) and the neighborhoods far from the IIUD, but that it is actually within the adjacent neighborhoods with shared similar socio-economic attributes prior to the implementation. This demonstrates the strength of the impact of the IIUD. The area of the BSID, as a result of the IIUD, has become more polarized and homogenous with more affluent residents earning higher incomes. Due in large part to its historical legacy with Route 128 , its proximity to Cambridge, and the high clustering of universities and research centers, Boston has a long history of courting high-tech industries and science and technology research (Saxenian, 1996), thus differing significantly to St. Louis and Buffalo. In this respect, as evident in Silicon Valley, Vancouver, London and the many other city-regions with a strong knowledge economy, Boston's long-standing shift towards a knowledge economy may explain the significant differences in variables across cases (Scott, 2006). However, this only furthers the argument on the importance of considering the negative consequences of IIUDs. To date, BSID is no longer considered an innovation district, meaning that the original intentions to build a space to catalyze regional growth by fostering a knowledge economy fell secondary to building a high-income neighborhood (Drucker et al., 2019).

\section{Concluding Thoughts and Policy Direction}

Emergent place-based strategies aiming to support a growing and robust knowledge economy, such as innovation districts, innovation hubs, and innovation zones, have gained in popularity amongst policy makers, planners, and local urban decision makers. Despite this popularity, there have been scant studies addressing potential negative consequences associated with such placebased strategies. In this article we address the rise of IIUDs and their connection to place. We argue that while achieving a strong and prosperous economy is a principle goal of economic developers, these local actors need to be equipped with studies that detail the negative consequences of IIUDs to inform pre-growth agendas and maximize inclusive growth within their jurisdictions.
The use of IIUD strategies is quickly and uncritically spreading to cities across the globe. As discussed above, scholars and practitioners depend on knowledge-based industries to grow national employment, Gross Domestic Product, and innovation and this influences regional and local economic development planning efforts (Drucker et al., 2019; L. F. Katz \& Krueger, 2016). In an effort to attract capital investment and human capital, IIUDs are based within a locality though they also function at a global level. While this is not unusual in the contemporary global era, what is important to recognize is how IIUDs may fail to address local needs as well as the sectoral differences between knowledge-based businesses (Zandiatashbar, Hamidi, \& Foster, 2019). Therefore, IIUDs need to include policies focused on local residents as a way to control for the increased polarized division of labor, housing unaffordability, unequal access to opportunities, and socio-spatial polarization that we found to be the potential negative consequences of IIUDs.

As IIUDs trend, this study is certain to be the first of many. In this last section, while recognizing the need and urgency for increased research, we discuss a few policy directions to curtail the negative consequences of IIUDs. For instance, local advocate-driven leadership coalitions considering IIUD strategies can create partnerships with a wide range of actors to better inform development decisions. In addition to the standard representatives from high-tech firms, universities, hospitals, and the city's or region's official decision makers, IIUD coalitions can also include local residents, NGOs, and social justice activists. Collectively, the coalitions define the vision and pillars for IIUDs, overseeing the associated policies and developments, advocating for empowering local residents through social equity, inclusiveness, and resources to train local residents to participate in the hightech job market.

As we show, IIUD strategies result in the spatial clustering of more affluent residents. In Boston, for instance, we observed that implementation of the IIUD led to a spatial core of high-tech high-wage jobs with a lower income diversification. Therefore, diversification of IIUDs should push beyond social, racial, and gender diversity to also focus on economic diversification of industrial activities and specializations. Diverse specializations could support social inclusion, lifelong learning, and robust R\&D activities (Niebuhr, 2010). Studies show that industries have different location behavior: While design and consulting firms are drawn to more walkable and transit accessible neighborhoods, advance manufacturing sectors are drawn to areas with strong auto-accessibility and proximity to airports (Zandiatashbar, Hamidi, \& Foster, 2019). Hence, this economic diversification can also balance the needs for both active and non-active mobility facilities and support better accessibility.

Rising housing prices as the result of the implementation of IIUDs is a major concern in the literature. While increased polarized division of labor and income inequality was not consistent across our three empirical cases, the 
rise of housing value was a common outcome of IIUD in our three cases. This calls for a strong focus on affordable housing within the IIUD, as well as in the neighborhoods surrounding it. However, this concept needs to merge with empowering local entrepreneurship. Multifamily rental properties in tech-hub cores are a better alternative to single-family homeownership assistance programs. Such properties allocate better access to jobs, while development of single-family houses in the urban core contribute to sprawl and congestion. Existing affordable housing policies could include mixed-residential and retail/office properties with retail or office uses to support owners' or renters' entrepreneurial activities. Including affordable office spaces in such mixeduse developments could support high-tech startup activities while affordable retail space could sustain other economic activities that do not necessary require techbased training. Implementing service amenities such as workforce development hubs, educational institutions, and workforce training opportunities in easy proximity to affordable housing residents is key.

As housing and land value inflation is capturing too much of the value of IIUDs, policymakers need to revisit and reserve the Land Value Taxation in IIUDs for mitigating the negative consequences of IIUDs. It is not only the tech businesses who could benefit from the IIUDs, but also large capital windfalls would go to landowners, as the result of attracting high-wage high-tech jobs, many of whom, according to Mulgon (2019), have contributed little to the wealth they capture. Hence, what is essentially needed in IIUDs is a novel approach to capturing land value gains within cities to divert them into new sources for mitigating the potential negative consequences of IIUDs.

In summary, though the Coronavirus pandemic of 2020 might recalibrate our understanding and role of cities, for the foreseeable future, IIUDs strategies will continue to reshape the socio-spatial demographic of the city. What we aim to demonstrate here is that an economic development practice increasingly attuned to and deriving profit from place has a responsibility to remain sensitive to its local residents. By first demonstrating the negative consequences associated with IIUDs and then pointing to possible policies to mitigate them, this article is a first step in the process.

\section{Acknowledgments}

The authors would like to acknowledge Dr. Shima Hamidi for her constructive comments on the methodology of the quasi-experimental analysis and Dr. Niamh MooreCherry for financing the open access license through University College Dublin.

\section{Conflict of Interests}

The authors declare no conflict of interests.

\section{References}

Aalbers, M. B. (2020). Financial geography III: The financialization of the city. Progress in Human Geography, 44(3), 595-607.

Acs, Z. J., Stam, E., Audretsch, D. B., \& O'Connor, A. (2017). The lineages of the entrepreneurial ecosystem approach. Small Business Economics, 49(1), 1-10.

Alonso, W. (1964). Location and land use. Cambridge, MA: Harvard University Press.

Bartik, T. J. (1991). Who benefits from state and local economic development policies? Kalamazzo, MI: W.E. Upjohn Institute.

Bell, D. (1976). The coming of post-industrial society: A venture in social forecasting (Vol. 5077). New York, NY: Basic Books.

Berkes, E., \& Gaetani, R. (2019). Income segregation and rise of the knowledge economy (Rotman School of Management Working Paper No. 3423136). Toronto: Rotman School of Management.

Bevilacqua, C., Pizzimenti, P., \& Maione, C. (2020). S3: Cluster policy and spatial planning. Knowledge $d y$ namics, spatial dimension and entrepreneurial discovery process. Brussels: European Union.

Boschma, R. (2005). Proximity and innovation: A critical assessment. Regional Studies, 39(1), 61-74.

Carrillo, F. J., Yigitcanlar, T., García, B., \& Lönnqvist, A. (2014). Knowledge and the city: Concepts, applications and trends of knowledge-based urban development. Abingdon: Routledge.

Catungal, J. P., \& Leslie, D. (2009). Contesting the creative city: Race, nation, multiculturalism. Geoforum, 5(40), 701-704.

Charnock, G., \& Ribera-Fumaz, R. (2011). A new space for knowledge and people? Henri Lefebvre, representations of space, and the production of 22@Barcelona. Environment and Planning D: Society and Space, 29(4), 613-632.

Chatman, D. G., \& Noland, R. B. (2011). Do public transport improvements increase agglomeration economies? A review of literature and an agenda for research. Transport Reviews, 31(6), 725-742.

Chesbrough, H., Vanhaverbeke, W., \& West, J. (Eds.). (2006). Open innovation: Researching a new paradigm. Oxford: Oxford University Press.

Clark, J. (2014). Siting 'scientific spaces' in the US: The push and pull of regional development strategies and national innovation policies. Environment and Planning C: Government and Policy, 32(5), 880-895.

Cochran, W. G., \& Rubin, D. B. (1973). Controlling bias in observational studies: A review. Sankhyā: The Indian Journal of Statistics, 35(4), 417-446.

Credit, K. (2017). Transit-oriented economic development: The impact of light rail on new business starts in the Phoenix, AZ region, USA. Urban Studies, 55(13), 2838-2862.

D’Albergo, E., \& Lefèvre, C. (2018). Constructing metropolitan scales: Economic, political and discur- 
sive determinants. Territory, Politics, Governance, 6(2), 147-158.

Donegan, M., \& Lowe, N. (2008). Inequality in the creative city: Is there still a place for "old-fashioned" institutions? Economic Development Quarterly, 22(1), 46-62.

Downs, A. (2005). Smart growth: Why we discuss it more than we do it. Journal of the American Planning Association, 71(4), 367-378.

Drucker, J. M., Kayanan, C. M., \& Renski, H. C. (2019). Innovation districts as a strategy for urban economic development: A comparison of four cases. Retrieved from https://ssrn.com/abstract=3498319

Fainstein, S. S. (2001). The city builders: Property development in New York and London, 1980-2000. Lawrence, KS: University Press of Kansas.

Fainstein, S. S. (2008). Mega-projects in New York, London and Amsterdam. International Journal of Urban and Regional Research, 32(4), 768-785.

Fallah, B., Partridge, M. D., \& Rickman, D. S. (2013). Geography and high-tech employment growth in US counties. Journal of Economic Geography, 14(4), 683-720.

Fincher, R., Pardy, M., \& Shaw, K. (2016). Place-making or place-masking? The everyday political economy of 'making place.' Planning Theory \& Practice, 17(4), 516-536.

Fingleton, B. (2008). Housing supply, housing demand, and affordability. Urban Studies, 45(8), 1545-1563.

Florida, R. (2002). The economic geography of talent. Annals of the Association of American Geographers, 92(4), 743-755.

Florida, R. (2014). The rise of the creative classRevisited: Revised and expanded. New York, NY: Basic Books.

Florida, R. (2017). The new urban crisis: How our cities are increasing inequality, deepening segregation, and failing the middle class-And what we can do about it. New York, NY: Basic Books.

Florida, R., \& Mellander, C. (2016). The geography of inequality: Difference and determinants of wage and income inequality across US metros. Regional Studies, 50(1), 79-92.

García, B. (2004). Urban regeneration, arts programming and major events: Glasgow 1990, Sydney 2000 and Barcelona 2004. International Journal of Cultural Policy, 10(1), 103-118.

Glaeser, E. L. (2011). Triumph of the city: How our greatest invention makes us richer, smarter, greener, healthier, and happier. London: Penguin Books.

Gouldner, A. W. (1979). The future of intellectuals and the rise of the new class. New York, NY: Seabury Press.

Grodach, C., Foster, N., \& Murdoch, J. (2018). Gentrification, displacement and the arts: Untangling the relationship between arts industries and place change. Urban Studies, 55(4), 807-825.

Hall, C. M. (2004). Sport tourism and urban regeneration. In B.W. Ritchie \& D. Adair (Eds.), Sport tourism:
Interrelationships, impacts and issues (pp. 192-205). Clevedon: Channel View Publications.

Hamidi, S. (2015). Measuring metropolitan form: Remaking urban form for sustainability. Salt Lake City, UT: The University of Utah.

Hamidi, S., \& Zandiatashbar, A. (2019a). Does urban form matter for innovation productivity? A national multilevel study of the association between neighbourhood innovation capacity and urban sprawl. Urban Studies, 56(8), 1576-1594.

Hamidi, S., \& Zandiatashbar, A. (2019b). Future @ Fort Worth: Capacity analysis, success factors, and growth vision for the Fort Worth Medical Innovation District (FW-MID) (CTEDD 019-01 IN). Arlington, TX: University of Texas at Arlington. Retrieved from https://ctedd.uta.edu/research-projects/futurefort-worth-capacity-analysis-success-factorsand-growth-vision-for-the-fort-worth-medicalinnovation-district-fw-mid

Harvey, D. (1989). The urban experience. Baltimore, MD: JHU Press.

Joint Venture Silicon Valley. (2019). 2019 Silicon Valley Index. San Jose, CA: Joint Venture Silicon Valley.

Katz, B., \& Bradley, J. (2013). The metropolitan revolution: How cities and metros are fixing our broken politics and fragile economy. Washington, DC: Brookings Institution Press.

Katz, L. F., \& Krueger, A. B. (2016). The rise and nature of alternative work arrangements in the United States, 1995-2015. Cambridge, MA: National Bureau of Economic Research.

Kayanan, C. M., \& Pajević, F. (2020). Bright lights, tech city for the no-collar worker (State of Power 2020 Report on The Corporation). Amsterdam: Transnational Institute. Retrieved from https://www.tni.org/ en/publication/bright-lights

Kayanan, C. M., Eichenmüller, C., \& Chambers, J. (2018). Silicon slipways and slippery slopes: Technorationality and the reinvigoration of neoliberal logics in the Dublin Docklands. Space and Polity, 22(1), 50-66.

Kayanan, C. M., Moore-Cherry, N., \& Tomaney, J. (2020). Metropolitan discursive constructions, implementation, and resistances: A survey on the formation of new metropolitan state spaces. Unpublished manuscript.

Lydon, M., \& Garcia, A. (2015). A tactical urbanism howto. In M. Lydon, \& A. Garcia (Eds.), Tactical urbanism: Short-term action for long-term change (pp. 171-208). Washington, DC: Island Press.

Markusen, A. (1999). Four structures for second tier cities. In A. R. Markusen, Y. Lee, \& S. DiGiovanna (Eds.), Second tier cities: Rapid growth beyond the metropolis (pp. 21-42). Minnesota, MN: Minnesota Press.

Marshall, A. (1890). Principles of economics. London: Macmillan and Co.

McCann, E. J. (2007). Inequality and politics in the cre- 
ative city-region: Questions of livability and state strategy. International Journal of Urban and Regional Research, 31(1), 188-196.

Modai-Snir, T., \& van Ham, M. (2018). Neighbourhood change and spatial polarization: The roles of increasing inequality and divergent urban development. Cities, 82, 108-118.

Mozingo, L. A. (2016). Pastoral capitalism: A history of suburban corporate landscapes. Cambridge, MA, and London: MIT Press.

Mulgon, G. (2019). Innovation districts: How cities speed up the circulation of ideas. Nesta. Retrieved from https://nesta.org.uk/blog/innovation-districts

Niebuhr, A. (2010). Migration and innovation: Does cultural diversity matter for regional R\&D activity? $P a-$ pers in Regional Science, 89(3), 563-585.

OECD. (2015). The metropolitan century: Understanding urbanisation and its consequences. Paris: OECD Publishing.

Osei, M. J., \& Winters, J. V. (2018). Labor demand shocks and housing prices across the US: Does one size fit all? (Discussion Paper No. 11636). Bonn: IZA. Retrieved from https://ssrn.com/abstract=3209733

Page, B., \& Ross, E. (2017). Legacies of a contested campus: Urban renewal, community resistance, and the origins of gentrification in Denver. Urban Geography, 38(9), 1293-1328.

Peck, J. (2005). Struggling with the creative class. International Journal of Urban and Regional Research, 29(4), 740-770.

Pishue, B. (2017). US traffic hotspots: Measuring the impact of congestion in the United States. Washington, DC: Transportation Research Board. Retrieved from http://www2.inrix.com/us-traffic-hotspot-study2017

Plosila, W. H. (2004). State science- and technologybased economic development policy: History, trends and developments, and future directions. Economic Development Quarterly, 18(2), 113-126.

Porat, M. U., \& Rubin, M. R. (1977). The information economy. Washington, DC: Department of Commerce, Office of Telecommunications.

Rifkin, J. (1995). End of work: The decline of the global labor force and the dawn of the post-market era. New York, NY: Putnam Publishing Group.

Roback, J. (1982). Wages, rents, and the quality of life. Journal of Political Economy, 90(6), 1257-1278.

Rosen, S. (1974). Hedonic prices and implicit markets: Product differentiation in pure competition. Journal of Political Economy, 82(1), 34-55.

Rossi, U., \& Di Bella, A. (2017). Start-up urbanism: New York, Rio de Janeiro and the global urbanization of technology-based economies. Environment and Planning A, 49(5), 999-1018.

Saxenian, A. (1996). Regional advantage. Cambridge, MA: Harvard University Press.

Scott, A. J. (2001). Global city-regions: Trends, theory, policy. Oxford: Oxford University Press.
Scott, A. J. (2006). Creative cities: Conceptual issues and policy questions. Journal of Urban Affairs, 28(1), 1-17.

Shearmur, R. (2012). Are cities the font of innovation? A critical review of the literature on cities and innovation. Cities, 29, S9-S18.

Smyth, H. (2005). Marketing the city: The role of flagship developments in urban regeneration. Abingdon: Taylor \& Francis.

Stiglitz, J. E. (2016). Inequality and economic growth. In M. Jacobs \& M. Mazzucato (Eds.), Rethinking capitalism (pp. 134-155). Oxford: Blackwell.

Turok, I. (1992). Property-led urban regeneration: Panacea or placebo? Environment and Planning A, 24(3), 361-379.

US Census Bureau. (2017). LEHD origin-destination employment statistics data (2002-2017). US Census Bureau. Retrieved from https://lehd.ces.census.gov/ data/\#lodes

US Census Bureau. (2018). American community survey 5-year estimates, 2013-2017 tables. US Census Bureau. Retrieved from https://www.census.gov/ programs-surveys/acs/technical-documentation/ table-and-geography-changes/2017/5-year.html

Voith, R. P., \& Wachter, S. M. (2009). Urban growth and housing affordability: The conflict. The Annals of the American Academy of Political and Social Science, 626(1), 112-131.

Weber, R. (2014). Tax increment financing in theory and practice. In S.B. White \& Z.Z. Kotval (Eds.) Financing economic development in the 21st century (pp. 297-315). Abingdon: Taylor \& Francis.

Weinreich, D., Hamidi, S., Bonakdar, A., Sardari, R., \& Moazzeni, S. (2019). Serving the riders that need it: Understanding the causes of service inequity in multijurisdictional transit agencies. Paper presented at the Transportation Research Board 98th Annual Meeting. Retrieved from https://trid.trb.org/view/1572990

Weissmann, J. (2012, March 25). Why don't young Americans buy cars? The Atlantic. Retrieved from https:// www.theatlantic.com/business/archive/2012/03/ why-dont-young-americans-buy-cars/255001

White, M. J. (1983). The measurement of spatial segregation. American Journal of Sociology, 88(5), 1008-1018.

Yigitcanlar, T., O'connor, K., \& Westerman, C. (2008). The making of knowledge cities: Melbourne's knowledgebased urban development experience. Cities, 25(2), 63-72.

Zandiatashbar, A., \& Hamidi, S. (2018). Impacts of transit and walking amenities on robust local knowledge economy. Cities, 81, 161-171.

Zandiatashbar, A., Hamidi, S., \& Foster, N. (2019). Hightech business location, transportation accessibility, and implications for sustainability: Evaluating the differences between high-tech specializations using empirical evidence from US booming regions. Sustainable Cities and Society, 50, 101648. 
Zandiatashbar, A., Hamidi, S., Foster, N., \& Park, K. (2019). The missing link between place and productivity? The impact of transit-oriented development on the knowledge and creative economy. Journal of Planning Education and Research, 39(4), 429-441.
Zlolniski, C. (2006). Janitors, street vendors, and activists: The lives of Mexican immigrants in Silicon Valley. Los Angeles, CA, and London: University of California Press.

\section{About the Authors}

Ahoura Zandiatashbar is Assistant Professor of Urban and Regional Planning at San José State University where he continues his empirical research on the U.S. geography of high-tech zones by exploring the role of urban form in equitable and robust knowledge economy, small firms' innovation productivity, and sectoral differences of high-tech zones. The results of his research have been presented in the Journal of Planning Education and Research, Journal of Urban Studies, and Cities; as well as more than 20 presentations and talks.

Carla Maria Kayanan is an Urban Planner, a Political Economist, and an Economic Geographer. Her research draws connections between the growth of the technology sector in the city and issues of homelessness and housing affordability. Currently she is studying metropolitan governance policies in relation to Ireland's new regional and economic spatial strategies as a Postdoctoral Researcher in University College Dublin's School of Geography. 